\begin{tabular}{|c|c|c|}
\hline & Int.J.Curr.Microbiol.App.Sci (2016) 5(8): $479-485$ & \\
\hline & International Journal of Current Microbiology and Applied Sciences & \\
\hline & ISSN: 2319-7706 Volume 5 Number 8 (2016) pp. 479-485 & \\
\hline $\begin{array}{l}\text { EXCELLENT } \\
\text { PUBLISHERS }\end{array}$ & & www ijomas,com \\
\hline
\end{tabular}

Original Research Article

http://dx.doi.org/10.20546/ijcmas.2016.508.051

\title{
Study the Optimum Parameters for Production of Cloned L-Asparaginase Type I by Escherichia coli
}

\author{
Maha Hameed A. Al.Bahrani* \\ Molecular and Medical Biotechnology Department, College of Applied Biotechnology, \\ Al-Nahrin University, Baghdad, Iraq \\ *Corresponding author
}

\begin{abstract}
A B S T R A C T
Keywords

L-Asparaginase, Escherichia coli, carbon and nitrogen sources.

Article Info

Accepted:

21 July 2016

Available Online:

10 August 2016

In the present study, medium components and production conditions were different for carbon and nitrogen sources. The results have shown that the best carbon and nitrogen sources were lactose and yeast extract at concentration $1 \%$. The different physiological factors include Temperature, $\mathrm{pH}$, aeration and agitation. Besides, the results showed that the maximum production of L-Asparaginase was achieved after the incubation of the growth culture at $30^{\circ} \mathrm{C}$ and $\mathrm{pH}$ 7.Under these conditions, the activity of L-Asparaginase produced in culture medium was $(10.3 \mathrm{IU} / \mathrm{ml})$ and $(10.5$ $\mathrm{IU} / \mathrm{ml}$ ) respectively. The production of L-Asparaginase was modified during E.coli grown aerobically and when the shaker incubated at $220 \mathrm{rpm}$.
\end{abstract}

\section{Introduction}

L-asparaginase is an amidohydrolase enzyme (EC 3.5.1.1) that catalyzes the hydrolysis of L-Asparagine (L-Asn) to LAspartate (L-Asp) and releases ammonia $\left(\mathrm{NH}_{3}\right)$. The activity of L-Asparaginaseis distributed in a number of microorganisms among plants, animals and others microorganisms, that include bacteria, yeast, fungi (Maria et al., 2004) such as E.coli (Kamble et al., 2012), Pseudomonas sp. (Ashraf et al., 2004), Erwinia sp. (Jyoti et al., 2011), Cryptococcus nodaensis (Sato et al., 1999). Penicillium (Kavitha and vijayalakshmi, 2010). The activity of Lasparaginase plays an important role in metaboling the nitrogen for prokaryotic and eukaryotic cells (Michel, 2003). On the other hand, the activity of LAsparaginase can be applied in different industrial and pharmaceutical purposes such as a processing aid in the food (David , 2005) and in the treatment of acute lymphoblastic leukemia (ALL) and some mast cell tumors (Bülbül and Karakuş, 2013). It also acts as a biosensor for monitoring the level of L-asparagine (Sabu et al., 2000). The aim of this study is to optimize the condition of culture in order to increase the productivity level of Asparaginase in recombinant E.coli BL21 DE3. The success of L-Asparaginase 
production mainly depends on the type of the microorganism and the media components that are used. Similarly, different physiological parameters have a greateffect on the production of enzymes. E.coli are reported to be very suitable for L-Asparaginase production (Siddalingeshwara and Lingappa, 2011).

This can be achieved by

1. Studying the effect of $\mathrm{pH}$;

2. Studying the effect of incubation temperature;

3. Studying the effect of different carbon and Nitrogen source;

4. Studying the effect of agitation (rpm);

5. Studying the effect of aeration.

\section{Materials and Methods}

Growth Media and Preparation of Solutions (Ausuble et al .,2007)

Luria-Bertani Broth (L.B): This media was prepared by dissolving $10 \mathrm{~g}$ of $\mathrm{NaCl}$, $5 \mathrm{~g}$ of yeast extract and 10 goftrypticase peptone in one liter of distilled water $\left(\mathrm{dH}_{2} \mathrm{O}\right)$ ( Bertani, 1952).

L.B Agar: This medium was prepared by dissolving $7.5 \mathrm{~g}$ of agar in one liter of LB broth media. M9 Media (Paglla et al., 2013). It was prepared by mixing $0.6 \mathrm{~g}$ $\left(\mathrm{Na}_{2} \mathrm{HPO}_{4}\right.$. 2H $\left.2 \mathrm{O}\right) ; 0.3 \mathrm{~g}\left(\mathrm{KH}_{2} \mathrm{PO} 4\right) ; 0.05$ $\mathrm{g}(\mathrm{NaCl}) ; 0.5 \mathrm{~g}$ (Asparagine); $0.2 \mathrm{~g}$ $\left(\mathrm{MgSO}_{4} .7 \mathrm{H}_{2} \mathrm{O}\right) ; 0.01 \mathrm{~g} \quad\left(\mathrm{CaCl} 2 \quad .2 \mathrm{H}_{2} \mathrm{O}\right)$; $20 \%$ of glucose stock and $3 \%$ of phenol red solution $(2.5 \%)$.

Tris Buffer (0.5M, pH 8) :This buffer was prepared by mixing $6.05 \mathrm{~g}$ of Tris $/ \mathrm{HCl}$, in $80 \mathrm{ml}$ of sterilized $\mathrm{dH}_{2} \mathrm{O}$.The $\mathrm{pH}$ was adjusted at 8, then the volume of buffer was completed to $100 \mathrm{ml}$.
L-asparagine $(0.04 \mathrm{M})$ and L-glutamine $(0.04 \mathrm{M})$ solutions: Both solutions were prepared by dissolving (0.05) $\mathrm{g}$ and (0.06) $\mathrm{g}$ of L-asparagine and L-glutamine respectively in $10 \mathrm{ml}$ of sterilized Tris base buffer $\mathrm{pH} 8$.

\section{Bacterial Strains and Culture Conditions (Ausuble et al., 2007)}

Recombinant BL21(DE3) plysS-T1R $E$. coli were grown over night at $37^{\circ} \mathrm{C}$ with $220 \mathrm{rpm}$ shahini stored at $-80^{\circ} \mathrm{C}$ for further analysis.

BL21 (DE3) Escherichia coli Strain was grown overnight in a shaking incubator at $37^{\circ} \mathrm{C}$ and $220 \mathrm{rpm}$. The overnight culture was diluted 1:100 into fresh M9 media. The cultures were incubated at $37^{\circ} \mathrm{C}$ with shaking at $220 \mathrm{rpm}$ until the optical density OD $600 \mathrm{~nm}$ wave length approximately reached to 1.7 .The growth culture was centrifuged at $10.000 \mathrm{rpm}$ for $15 \mathrm{~min}$, then the supernatant was used for the quantitative analysis of LAsparaginase.

\section{Enzyme Assay}

Amidohydrolase enzyme assay was assayed according to Mannan et al., (1995): International Unit (IU):One international unit of Putative Lasparaginase or L-glutaminase is the amount of enzyme which liberates $1 \mu \mathrm{mol}$ of ammonia per minute per $\mathrm{ml}$ [ $\mu \mathrm{mole} / \mathrm{ml} / \mathrm{min}]$.

\section{Optimal Conditions for L- Asparaginase Production}

Optimal conditions for the production of L-asparaginase from recombinant E.coli BL21 DE3were studied in order to obtain a higher enzyme production, as follows: 


\section{Optimum Carbon Source}

The effect of different carbon sources on L-Asparaginase production (glucose, lactose, D-sorbitol and maltose) by recombinant E.coli BL21 DE3 was used to determine the optimum carbon source for enzyme production. Each carbon source was individually added to the production media of about $1 \%(\mathrm{w} / \mathrm{v})$ as a final concentration

\section{Effect of Nitrogen Source}

Different nitrogen sources were tested to determine the optimum one for LAsparaginase production. Nitrogen sources used in this study involved $1 \%$ w/v (Yeast extract, peptone, ammonium sulphate and mixture of L-asparagine and L-Glutamine).

\section{Effect of Temperature on Production of L-asparaginase}

The productivity level of L-Asparagine was determined after incubating the bacterial culture at different temperature values ranging from 25 to $50^{\circ} \mathrm{C}$.

\section{Effect of $\mathrm{pH}$ on Production of L-} asparaginase

Activity of L-asparaginase in the production media was measured at various $\mathrm{pH}$ values to study the effect of $\mathrm{pH}$ on the production of both enzymes. The $\mathrm{pH}$ media was adjusted at different $\mathrm{pH}$ values ( $\mathrm{pH}$ 5.0-9.0). Bacterial cultures were incubated at $37^{\circ} \mathrm{C}$ and the activity of the enzyme was measured.

\section{Effect of Agitation (rpm)}

The effect of agitation on the production of L-asparaginase was determined at vary agitation speeds of 50,100,220 and 250 rpm at $37^{\circ} \mathrm{C}$ for $18 \mathrm{~h}$.
Effect of Aeration (volume of media to air-space of flask)

In order to study the effect of aeration on the production of L-asparaginase, different volumes (50, 100, 150 and 200 $\mathrm{ml}$ ) of production medium were used in $250 \mathrm{ml}$ flasks, and then tested for a maximum L-asparaginase production.

\section{Results and Discussion}

Effect of Carbon Sources on the Production of L-Asparaginase

L-Asparaginase production responded differently to various carbon sources at $1 \%(\mathrm{w} / \mathrm{v})$. The results in figure (1) showed that the efficient L-asparaginase production occurred when lactose was used as a carbon source in a basal medium. The activity of L-asparaginase in a crude culture reached (10.89) U/ml while the low activity was when glucose, maltose and D-sorbitol were used as carbon sources.

\section{Effect of Different Nitrogen Sources}

Different nitrogen sources were used to determine their effect on the productivity of Asparaginase. As illustrated in figure (2), the results showed that the yeast extract at $0.5 \%(\mathrm{w} / \mathrm{v})$ produced a maximum L-Asparaginase. Whereas other supplemented nitrogen sources showed a significant viable effect on both amidohydrolase activities.

\section{Effect of Incubation Temperature}

The maximum production of LAsparaginase was observed when the culture media incubated at $30{ }^{\circ} \mathrm{C}$ (figure.3). Under this condition the L-Asparaginase activity reached $10.3 \mathrm{IU} / \mathrm{ml}$. 
Fig.1 Effect of Carbon Source on Production of L- Asparaginase

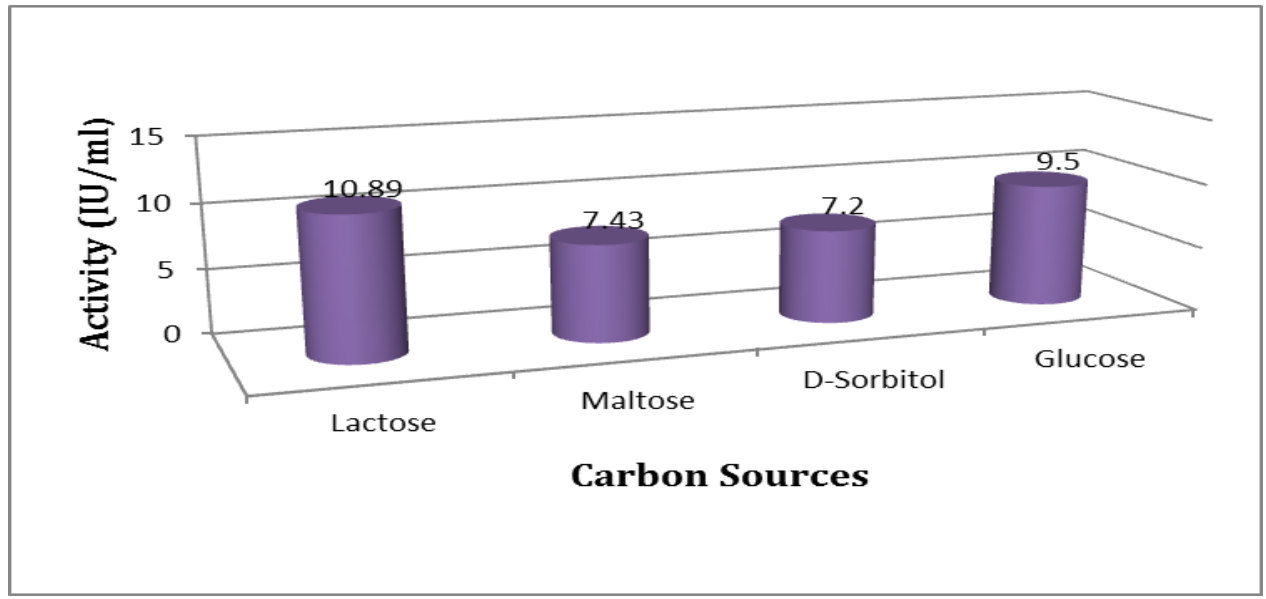

Fig.2 Effect of Different Nitrogen Sources on L-Asparaginase Production

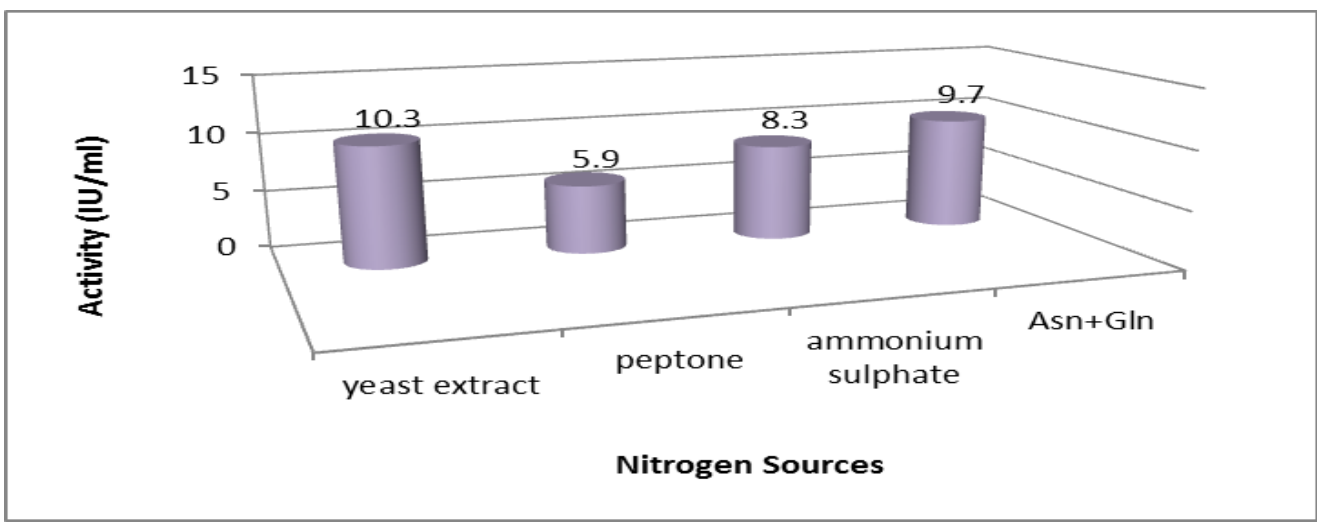

Fig.3 The Optimum Temperature Value for Maximum L-Asparaginase Production

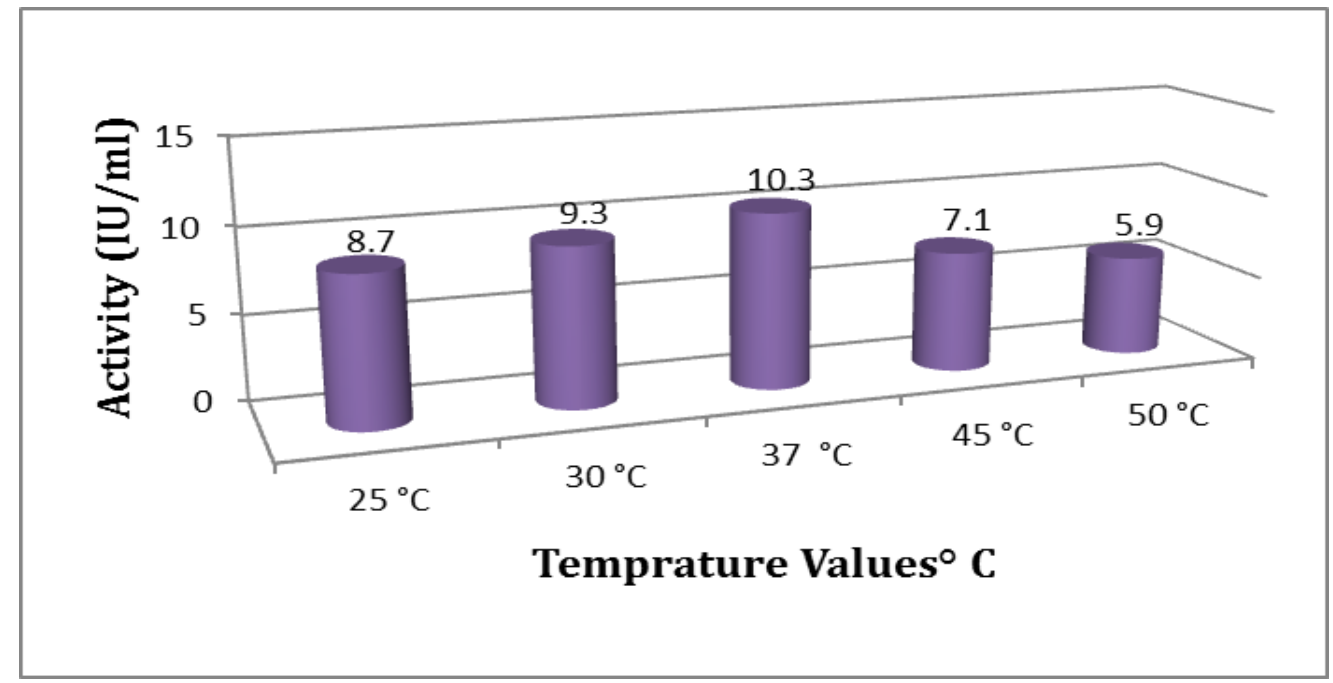


Fig.4 Effect of pH Values on Production of L-Asparaginse

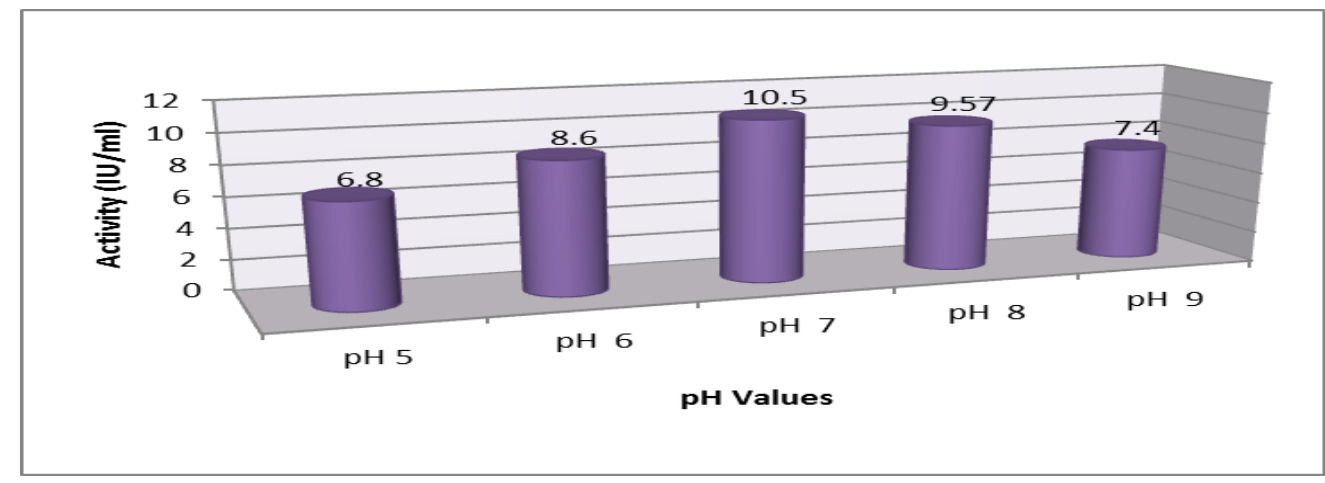

Fig.5 Effect of Agitation on the Production of L-Asparaginase

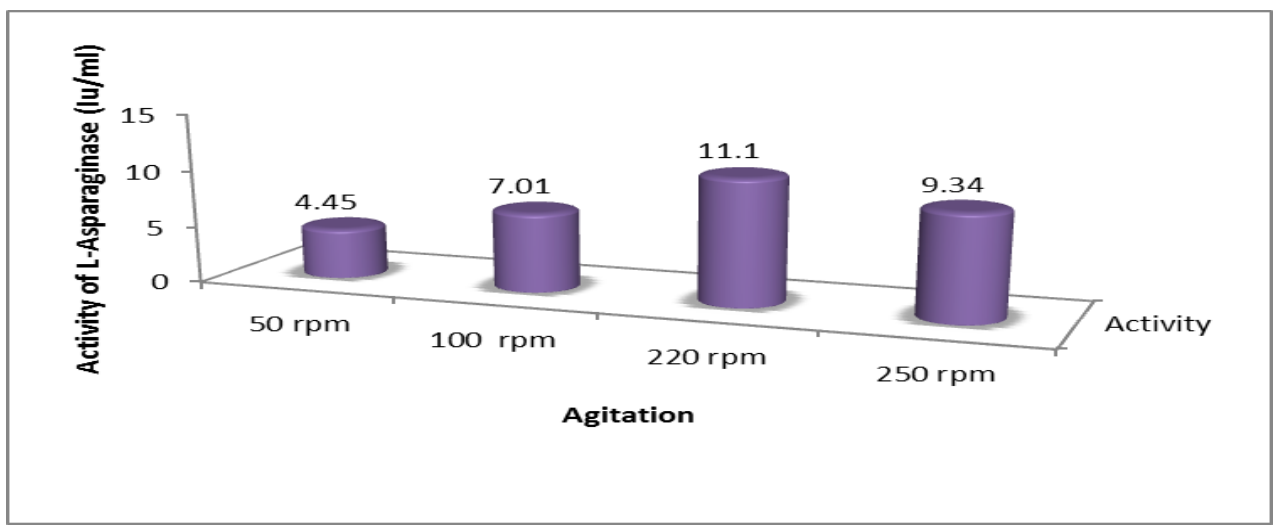

Fig.6 Effect of Aeration (Volume of Media to Space of Flask)

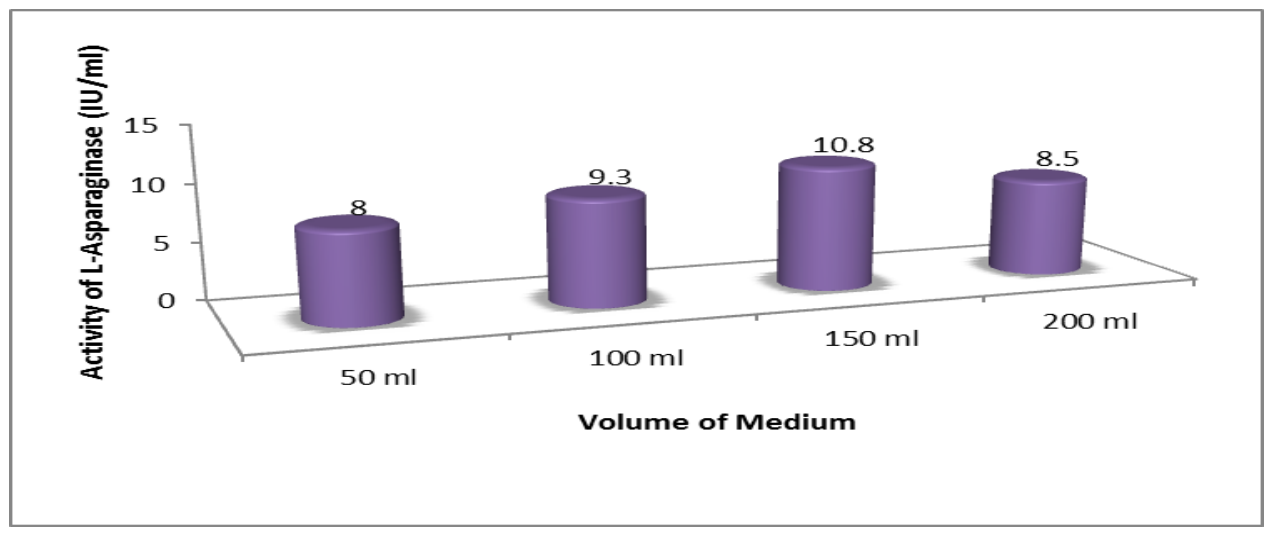

\section{Effect of Initial pH Medium}

The effect of initial $\mathrm{pH}$ media on amidohydrolase activity was tested at various $\mathrm{pH}$ values. As it is shown in figure (4), the maximum activity of L-
Asparaginase was obtained when the culture media of recombinant E.coli was adjusted at $\mathrm{pH} 7$. At this $\mathrm{pH}$ value, the activity of L-Asparaginase was (10.5 $\mathrm{U} / \mathrm{ml}$ ) 
E.coli has the ability to produce large amounts of L-asparaginase in alkaline and conditions more than acidic conditions. The change that occurred in $\mathrm{pH}$ value of culture media may be attributed to the metabolism of bacteria. This change may have an effect on the biological cells and solubility and on ionizing the nutrition substrates.All of these reasons negatively affect the enzyme activity and may lead to a distortion in the three dimation of enzyme (Tortora et al., 2004; Hammami et al., 2007).

\section{Effect of Agitation Speed (rpm)}

The effect of agitation speed on LAsparaginase was reported in figure (5). The results shown that there was a gradual increase in the activity of the LAsparaginase at $220 \mathrm{rpm}$. It was found that the activity of L- Asparaginase was (11.1 U/ml).

\section{Effect of Aeration on L-Asparaginase Production}

The results shown in figure 6 , is howed that the optimum production of LAsparaginase was found when the volume of media was $100 \mathrm{ml}$. The activity of LAsparaginase was 10.8 (IU/ml).

In conclusion, there were many potential bacteria strains with a good L-asparaginase activity and they have beensuccessfully isolated. Different strains showed the highest L-asparaginase activity $(11.1 \mathrm{IU} / \mathrm{ml})$. It is recommended to isolate the gene that is responsible for the production LAsparaginase type I and to optimize the production of enzyme from new thermophilic bacterial strains that could be considered important sources to be used in the industrial L-asparaginase production. The latter is considered a potential source of useful microbes that can be used as a source in different biological products such as enzymes.

\section{References}

Ashraf, A., Sarhan, M. and Mansour, J. 2004. Production, Isolation, and Purification of L-Asparaginase from Pseudomonas Aeruginosa50071 Using Solid-state Fermentation. $J$. Biochem. Mol. Biol., Vol. 37(4): P. 387-393.

Ausuble, F.M., Brent, R. and Kingston, R. E., Moore, D.D., Sedman, J.G., Smith, J.A. and Struhl, K. 2007.Current protocol in molecular biology. NewYork: John Wiley and sons.

Bülbül, D. and Karakuş, E. 2013. Production and optimization of Lglutaminase enzyme from Hypocrea jecorina pure culture. Prep. Biochem. Biotechnol., 43(4): p.38597.

David, S. 2005. The Molecular Perspective: L-Asparaginase. The Oncologist, 10: P.238-239.

Hammami, R., Zouhir, A., Ben Hamida, J. and Fliss, I. 2007. Bacteriocin Characterization. BMC Microbiol., 17(7): P.89.

Jyoti, H., Shivaveera, $\mathrm{k}$.and Vandana, R. 2011. Production of L-glutaminase by Pseudomonas VJ-6. J. Biotechnol., 6(3): P. 42-49.

Kamble, K., Bidwe, P., Muley, V., Kamble, L., Bhadange, D. and Musaddiq, M. 2012. Characterization of L-Asparaginase producing bacteria from water, farm and saline soil. Biosci. Discovery, 3(1): 116119.

Kavitha, A. and Vijayalakshmi, M. 2010. Optimization and purification of LAsparaginase produced by Streptomyces tendae TK-VL_333. J. Naturforsch C., 65(7-8): 528-531. 
Manna, S., Sinha, A., Sadhukhan, R. and Chakrabarty, S. 1995. Purification, characterization and antitumor activity of L-Asparaginase isolated from Pseudomonas stutzeri MB-405. Curr. Microbiol., 30(5): P.291-298.

Maria, I., Edna, M., Alberdan, S. and Gisela L. 2004. Production of LAsparaginase by Filamentous Fungi, Mem. Inst. Oswaldo Cruz , Rio de Janeiro. vol.99 (5).

Michel, V. 2003. The enzyme as a drug: application of enzyme as pharmaceuticals. Curr. opinion in Biotechnol., 14: P.444-450.

Paglla, U., Rao, C. and Rajulapati, S. 2013. Studies on L-Asparaginase Production by Using Staphylococcus Capitis. J. Chem. Bio. Phy. Sci. Sec., B, Vol.3(1): 201-209.

Sabu, A. 2000. L-Glutaminase Production by Marine Fungi. Ph.D thesis submitted to Cochin University of Science and Technology.

Sato, I., Kobayashi, Y., Hanya, K., Abe, K., Murakami, S., Scorzetti, G. and Fell, J. 1999. Crypyococcus nodaensis sp. Nov, ayeast isolated from soil in jaban that produced a salt tolerant and thermstableglutaminase. J. Indus. Microbiol. Biotechnol., 22: P.127132.

Siddalingeshwara, K.G. and Lingappa, K. 2011. Production and charectrization of L-asparaginase-Tumor inhibitor, Int. J. Pharm. Tech. Res., Vol. 3(1): P. 314-319.

Tortora, G., Funke, B. and Case, C. 2004. Microbiology 8th. Ed. Pearson Benjamin Cummings. United States of America.

\section{How to cite this article:}

Maha Hameed A. Al.Bahrani. 2016. Study the Optimum Parameters for Production of Cloned L-Asparaginase Type I by Escherichia coli. Int.J.Curr.Microbiol.App.Sci. 5(8): 479-485. doi: http://dx.doi.org/10.20546/ijcmas.2016.508.051 